\title{
Kearifan Lokal Arsitektur Tradisional Kasepuhan Sinar Resmi Cisolok Sukabumi
}

\author{
Sutisna ${ }^{1} *$ Yudi Falahi ${ }^{1}$ Jaya Wiharja ${ }^{1}$ Iis Sunaryanti ${ }^{1}$ \\ ${ }^{1}$ Program, Magister PPKn STKIP Arrahmaniyah Depok, Indonesia
}

\begin{abstract}
Abstrak-Masyarakat adat yang masih tetap eksis, telah memelihara kearifan lokal menjadi bagian yang tidak terpisahkan dari kehidupan sehari-hari dan menjadi dasar bagi solusi terhadap permasalahan yang terjadi di masyarakatnya. Pada umumnya, suatu budaya diwariskan oleh leluhur secara turun temurun dari satu generasi ke generasi selanjutnya. Permukiman Kasepuhan Sinar Resmi merupakan bentuk dari kebudayaan fsik. Manusia memandang sebuah rumah tidak hanya sebagai tempat tinggal dan tempat bernaung, namun terdapat dimensi citra yang menyebabkan adanya pemaknaan pada bangunan serta ruang tempat tinggalnya. Tujuan penelitian ini adalah untuk mendapatkan gambaran secara utuh dan mendalam tentang arsitektur serta mengungkap simbol dan nilai filosofis masyarakatnya. Metode penelitian adalah metode kualitatif dengan teknik pengumpulan data berupa observasi langsung dan wawancara. Arsitektur, merupakan buah karya yang tak lepas dari simbol dan nilai yang melekat pada masyarakat pendukungnya, sehingga tata cara pembangunan tidak ditinggalkan walaupun perubahan terus melanda. Keteguhan dalam mempertahankan adat ini menjadi ciri mandiri dalam menghasilkan bentuk arsitektur yang ada di Sinar Resmi.
\end{abstract}

\author{
Kata kunci: \\ Kearifan Lokal, \\ Arsitektur Tradisional, \\ Kasepuhan Sinar Resmi
}

\section{Histori:}

Dikirim: 20 Agustus 2021

Direvisi: 29 September 2021

Diterima: 30 September 2021

Online: 30 September 2021

\section{Identitas Artikel:}

Sutisna, M., Falahi, Y., Wiharja, J., \& Sunaryanti, I. (2021). Kearifan Lokal Arsitektur Tradisional Kasepuhan Sinar Resmi Cisolok Sukabumi. Jurnal Citizenship Virtues, 1(2), 124-136.

\section{PENDAHULUAN}

Konsep kearifan lokal berakar dari sistem pengetahuan dan pengelolaan lokal atau tradisional. Koentjaraningrat (2015) menjelaskan kearifan lokal mewakili sistem nilai dan norma yang disusun, dianut, dan diaplikasihan masyarakat berdasarkan pemahaman dan pengalaman mereka dalam berinteraksi dan berinterelasi dengan

\footnotetext{
$1_{*}$ Corresponding author.

E-mail: yudifalahi900606@gmail.com
} 
lingkungan. Kearifan lokal memiliki dimensi sosial dan budaya yang kuat, karena memang lahir dari aktivitas perlakuan berpola manusia dalam kehidupan bermasyarakat. Kearifan lokal dapat menjelma dalam bentuk seperti ide, gagasan, nilai, norma dan peraturan dalam ranah kebudayaan, sedangkan dalam kehidupan sosial dapat berupa sistem religius, sistem dan organisasi kemasyarakatan, sistem pengetahuan, sistem mata pencaharian hidup, system teknologi dan peralatan. Selanjutnya Adimihardja (2008) menggunakan istilah kearifan lokal dengan Sistem Pengetahuan dan Teknologi Lokal (STPL). Kearifan lokal masyarakat dapat diamati pada ekpresi nyata (tangible) seperti produksi kesenian rakyat dalam bentuk gambar, lukisan, pahatan, keramik dan gerabah, mosaik, ukiran dari kayu, metal, perhiasan, sulaman kain, permadani dan pakaian; kerajinan rakyat; instrumen musik; dan bentuk-bentuk arsitektur. Kearifan lokal (local wisdom) merupakan pengetahuan yang dikembangkan didalam suatu masyarakat, yang didapatkan melalui proses trial \& error terhadap lingkungan fisiknya, seperti terhadap gempa, banjir, dan lain-lain. Pengetahuan tersebut banyak tersimpan didalam suatu masyarakat lokal yang diterapkan terhadap lingkungan binaannya, seperti bangunan (rumah tinggal) (Triyadi dan Harapan, 2008). Sebagai contoh rumah adat di Kasepuhan Sinar Resmi Jawa Barat masih berdiri kokoh, kendati di wilayah kabupaten tersebut pernah diguncang gempa dengan kekuatan $\pm 6.8 \mathrm{SR}$ pada tahun 2018 (Pudjiastuti;2019), tetapi rumah-rumah penggung di Kasepuhan Sinar Resmi tidak ada yang roboh atau hancur, karena bagi masyarakat Kasepuhan Sinar Resmi, bentuk rumah panggung merupakan wujud harmonisasi antara manusia alam, dan Tuhan. Sedangkan rumah-rumah permanen yang terbuat dari dinding bata yang ada di sekitar Kasepuhan Sinar Resmi banyak yang roboh dan hancur akibat gempa. Rumah panggung di Kasepuhan Sinar Resmi menggunakan sistem kolong, pondasi umpak, atap dari ijuk dilapis daun rumbia, dengan dinding gedeg atau bilik bambu. Keistimewaan rumah panggung memang ternyata mampu mengimbangi gerakan tanah, dan lentur (elastisitas), sehingga aman terhadap guncangan gempa, baik secara horisontal maupun vertikal.

Bentuk rumah masyarakat kasepuhan Sinar Resmi pada umumnya adalah panggung. Panggung yaitu rumah berkolong dengan menggunakan pondasi umpak. Tinggi umpak dari permukaan tanah $\pm 40-60 \mathrm{~cm}$. Kolong di bawah lantai rumah dipakai untuk berbagai keperluan seperti menyimpan kayu bakar, gudang bahan bangunan, kandang ayam, itik dan lain-lain. Secara umum, masyarakat kasepuhan Sinar Resmi mengenal tiga jenis umpak, yaitu: bentuk utuh (bulat), yaitu batu alam yang diambil dari sungai bekas letusan gunung pada masa lampau, merupakan batu tanpa pengerjaan lebih lanjut dan biasa dipakai untuk alas kaki golodog. Bentuk lesung (lisung), yaitu batu berbentuk balok yang berdiri tegak dengan permukaan pada sisi alas lebih kecil daripada permukaan sisi bawah, banyak dipakai pada rumah dan leuit. Bentuk kubus (balok), yaitu batu berbentuk kubus ditegakkan dengan sisi-sisi atas dan bawah sama besar (Garna, 1984). Menurut Adimihardja (1997), panggung merupakan bentuk bangunan yang paling 
penting bagi masyarakat Sunda, dengan suhunan panjang dan tambahan teritis pada bagian depan dan belakang serta suhunan jure, bentuk atap perisai yang memanjang. Kedua bentuk atap tersebut merupakan bentuk atap bangunan yang lazim dikenal di kalangan penduduk di pedesaan Jawa Barat. Teknologi panggung pada bangunan rumah ini dimungkinkan untuk memberikan kehangatan pada penghuninya. Bagian kolong dari panggung tersebut biasa digunakan untuk menyimpan alat-alat pertanian atau kayu bakar.

Secara arsitektural, rumah-rumah tradisional menunjukkan usaha adaptasi dengan lingkungannya, sehingga letak, arah, dan bentuk sangat serasi, dengan mempertahankan tata aturan dan adat- istiadat warisan budaya nenek moyang (Sumintardja ;1978). Di samping bentuknya, dapat pula dilihat dari pola perkampungan yang dicirikan dengan adanya aliran sungai, perkampungan terletak di lembah, pola perumahan yang mengelompok, semuanya menyerupai dengan kampung-kampung adat yang tersebar di wilayah budaya Sunda (Rusnandar ;2000). Permukiman tradisional di Jawa Barat mempunyai sejumlah persamaan dan perbedaan, mengalami perubahanperubahan, dan sedang mengalami tantangan akan kebertahanannya. Di sini bekerja kearifan- kearifan komunitas adat terhadap lingkungannya, yang menentukan apakah mereka dapat bertahan terhadap perubahan atau tidak (Belgawan, 2011).

Ada dua hal yang dapat dibedakan, yaitu antara rumah tradisional dan rumah adat; rumah tradisional adalah rumah yang apabila pembangunan dan aktivitas- aktivitasnya didasarkan pada kebiasaan yang dijalankan secara turun-temurun walaupun dalam perjalanan waktu ada perubahan-perubahan dan dinamika. Dalam aspek mendirikan rumah atau unsur-unsur lainnya terutama dalam pelaksanaannya terdapat apa yang disebut pragmatika (the pragmatics), yaitu kebiasaan yang melekat di dalam menjalankan proses membangun suatu unsur bangunan. Sedangkan rumah adat, yaitu apabila pendirian rumahnya, selalu mengikuti aturan-aturan adat, bagaimana tata cara penggunaan bahan, perletakkan rumah, bentuk rumah, upacara-upacara, dan sebagainya. Aturan-aturan ini mengandung "sanksi", bisa yang kongkrit berupa sanksi adat, atau berupa tabu yang menyiratkan akibat-akibat apabila dilanggar. Namun demikian, di antara keduanya dengan sendirinya juga terdapat"tradisi" terkait dengan aktifitas mendirikan rumah/permukiman dan aktivitas bermukim pada umumnya, karena adanya aturan-aturan adat juga berarti mentradisikan hal-hal tersebut. Seorang pengamat arsitektur vernakular, Oliver (1997), dalam tulisannya menyebutkan bahwa arsitektur dari rumah yang tumbuh dan berkembang berdasarkan tradisi seperti ini adalah berkembang atas dasar tradisi "vernakular". Rumah sebagai hasil cipta karyaarsitektural, adalah cetusan ide yang diselaraskan dengan konteks alam yang dihadirkan dalam bentuk bangunan, baik dalam interior maupun eksterior. Jadi pengaruh lingkungan pada tatanan ruang dimana karya 
arsitektur didirikan sangat berperan terhadap pencetusan ide-ide dari sebuah desain arsitektur. Seperti halnya rumah tradisional, selain dibentuk dan dikomposisikan berdasarkan aturan adat juga berdasarkan bahan-bahan yang ada di alam. Berbicara mengenai arsitektur tradisional, secara spesifik tidak lepas dari nilai-nilai budaya setempat. Dalam perkembangannya, arsitektur sebagai sebuah karya yang tak lepas dari pengaruh budaya luar, sehingga banyak karya arsitektur yang keluar dari unsur kedaerahannya. Berkaitan dengan hal tersebut, arsitektur tradisional Jawa Barat, khususnya arsitektur rumah di Kampung Kasepuhan Sinar Resmi Kabupaten Sukabumi perlu dilestarikan keberadaannya, hal tersebut disebabkan derasnya sentuh budaya yang dinamis yang memengaruhi bentuk-bentuk bangunan dari masa ke masa.

Kampung Kasepuhan Sinar Resmi, merupakan salah satu kampung adat yang berada di wilayah Jawa Barat tepatnya Kecamatan Cisolok Kabupaten Sukabumi, masyarakatnya masih teguh memegang adat istiadat. Dengan demikian masyarakat ini bisa dikatakan sebagai komunitas adat yang kuat. Salah satu karya yang dihasilkan oleh komunitas ini ada dalam bentuk arsitektur, sehingga hasil yang dicapai dalam karyanya merupakan cerminan kuat dari latar belakang budaya yang melingkupinya. Buah karya masyarakat komunitas adat dalam bidang arsitektur, merupakan cerminan atau meminjam istilah sastra disebut mimesis kehidupan komunitas itu sendiri yang berkaitan erat dengan tempat ia berada. Maka pada hasilnya arsitektur merupakan hasil bentukan dan rupa bangunan yang terkait erat dengan lingkungan ia berada, untuk mengadaptasikan diri sesuai dengan pengalaman serta ide-idenya. Koentjaraningrat (2015) menyebutkan bahwa kebudayaan adalah keseluruhan gagasan dan karya manusia yang harus dibiasakannya dengan belajar, berserta keseluruhan dari hasil budi dan karyanya itu. Proses adaptasi antara manusia dan lingkungannya dicerminkan dalam cipta, rasa, dan karsa sehingga terlahir jiwa harmonis di antara keduanya. Manusia mengerti dengan sifat-sifat alamnya, sehingga alamnya akan memberi keseimbangan dalam keharmonisan yang terjaga. Hal tersebut terjadi karena pola pikir manusia pendukungnya selalu menyelaraskan dengan sifat alam yang ditempatinya.

Perubahan yang dirasakan dalam pembangunan, terus melanda hingga di pedesaan, khususnya di Kampung Kasepuhan Sinar Resmi, telah menyebabkan pergeseran terhadap wujud- wujud kebudayaan yang terkandung dalam bentuk arsitektur tradisionalnya. Karya seni arsitektur kini lebih menonjol nilai artifisial dibanding nilai fungsionalnya, sehingga karya seni arsitektur itu kadang- kadang bahkan malah sering tak bernada nilai kedaerahan. Sebagai contoh yang terjadi di Sinar Resmi sendiri, dewasa ini sudah muncul rumah yang bertembok dan beratap tidak lagi mempergunakan hateup, melainkan genting dan asbes. Permasalahan yang muncul dalam penelitian ini adalah perubahan yang terjadi pada ciri arsitektural di Kampung Sinar Resmi, serta nilai-nilai yang terkandung dalam arsitektur. Ruang lingkup daerah penelitian, yaitu Kasepuhan Sinar Resmi di Kabupaten Sukabumi yang merupakan salah satu Kampung Adat di Jawa Barat. Ruang 
lingkup penelitian, hal yang berkaitan dengan struktur bangunan, fungsi bangunan, bentuk bangunan dan nilai-nilai yang terkandung di dalamnya.

\section{METODE PENELITIAN}

Kajian ini menggunakan paradigma kualitatif dan metode naratif dengan strategi pembahasan secara deskriptif. Hal ini dilakukan karena penulis bertujuan untuk mendeskripsikan dan menumbuhkembangkan pengetahuan mengenai pemaknaan kembali kerifan lokal dalam arsitektur. Pada kajian tidak terdapat satu objek atau lokus studi tertentu yang menjadi acuan analisis. Kajian ini fokus untuk mengungkapkan kembali mengenai dasar pemahaman dari kearifan lokal dan pemaknaannya dalam arsitektur. Dalam kajian ini dilakukan studi dari data sekunder berupa buku, jurnal ilmiah dan data-data terkait. Dengan dilakukannya kajian ini, diharapkan dapat memberi kontribusi dalam upaya pemaknaan kembali kearifan lokal dalam arsitektur dan menumbuh-kembangkan cara pikir arsitektural mengenai keberlanjutannya.

Penelitian ini dilakukan dengan tiga cara, yaitu: (1) observasi partisipasi (participant observation), (2) wawancara mendalam (in-depth interview), dan (3) penggunaan dokumen (dokument used). Teknik observasi partisipasi. Partisipan bertindak sebagai pengamat aktif dengan menyaksikan dan mengikuti kegiatan yang dilakukan, mencatat dan melakukan tanya jawab dengan informan, kemudian dilanjutkan dengan analisis secara cermat tentang apa yang telah diamati tersebut. Wawancara terbuka atau mendalam, yang memberi keleluasaan bagi informan untuk memberi pandangan - pandangan secara bebas. Kemudian teknik wawancara dilakukan dengan melakukan wawancara dengan nara sumber yang berkaitan dengan penelitian yang dikaji.(Pudjiastuti;2019) Wawancara demikian ini memungkinkan si peneliti untuk mengajukan pertanyaan-pertanyaan secara mendalam. Karena itu, untuk melengkapi data penelitian ini, khususnya dalam upaya memperoleh data yang akurat tentang penelitian ini, peneliti melakukan wawancara dengan informan. Dalam penelitian ini, wawancara yang akan digunakan adalah wawancara yang mendalam atau wawancara tak berstruktur.

\section{HASIL DAN PEMBAHASAN}

Permukiman yang ada di Sinar Resmi hampir sama dengan pola pemukiman masyarakat adat yang ada di daerah Sukabumi Selatan, yaitu pola permukiman yang mengelompok dengan membangun rumah di badan perbukitan, sehingga menempatkan rumahnya di tempat lahan yang berkontur. Tata letak bangunan rumah tampak teratur. Sinar Resmi merupakan pusat kasepuhan, di dalam kawasan Kampung Sinar Resmi terdapat 111 kepala keluarga dan sebagian penduduk atau warganya tersebar di berbagai kampung kecil yang terdiri atas 10-30 rumah, yang membentuk babakan (perkampungan), pola perkampungan (the farm village type) dengan pusat kota sebagai perkampungan terbesar. Babakan (perkampungan) itu dibentuk dalam satu 
keluarga besar, setiap pola perkampungan ini biasanya dihubungkan oleh akses jalan setapak.

Bentuk panggung yang mendominasi sistem bangunan di kasepuhan Sinar Resmi mempunyai dua fungsi, yaitu: (1) Fungsi teknik; dan (2) Fungsi simbolik. Secara teknik rumah panggung memiliki tiga fungsi, yaitu: tidak mengganggu bidang resapan air, kolong sebagai media pengkondisian ruang dengan mengalirnya udara secara silang baik untuk kehangatan dan kesejukan, serta kolong juga dipakai untuk menyimpan persediaan kayu bakar dan lain sebagainya. Fungsi secara simbolik didasarkan pada kepercayaan Orang Sunda, bahwa dunia terbagi tiga: ambu handap, ambu luhur, dan ambu tengah. Ambu tengah merupakan pusat alam semesta dan manusia menempatkan diri sebagai pusat alam semesta, karena itulah tempat tinggal manusia harus terletak di tengah-tengah, tidak ke ambu handap (dunia bawah/bumi) dan ambu luhur (dunia atas/langit). Dengan demikian, rumah tersebut harus memakai tiang yang berfungsi sebagai pemisah rumah secara keseluruhan dengan dunia bawah dan atas. Tiang rumah juga tidak boleh terletak langsung di atas tanah, oleh karena itu harus di beri alas yang berfungsi memisahkannya dari tanah yaitu berupa batu yang disebut umpak (Adimihardja, 1997).

Lantai rumah terbuat dari papan kayu atau bambu, dibentuk melebarpanjang menjadi talupuh atau palupuh. Bahan untuk rangka utama rumah, tiang, rangka atap, bagian atas dinding dan penjepit dinding terbuat dari kayu albasiah, malaka dan sejenisnya. Batang kelapa juga sering digunakan sebagai bahan bangunan, terutama untuk tiang utama rumah. Atap rumah terbuat dari anyaman daun kiray, alang-alang, daun nipah, daun kelapa, ijuk dan genteng. Pada sebagian kampung adat di Jawa Barat, terdapat larangan penggunaan genteng karena bertentangan dengan aturan adat leluhurnya. Dinding rumah terbuat dari anyaman bilik bambu dipasang dua lapis (luar-dalam), agar tidak dingin maka bilik dilapisi dengan kapur atau kertas semen. Selain bilik, digunakan juga papan yang dipasang susun sirih. Sedangkan bagian atap menggunakan struktur rangka dari material bambu kombinasi kayu dan penutupnya dari ijuk, daun rumbia atau kiray, sehingga terlihat ringan. Konstruksi rangka bangunan menggunakan paseuk (pasak) dan tali rotan, tanpa paku karena dilarang adat. Walaupun demikian, struktur dan konstruksinya tetap kuat dan kokoh. Kekuatan dan kekokohan rumah panggung bukan didasarkan pada teknologinya, tetapi berdasarkan pada kearifan lokalnya. Masyarakat Sunda percaya, bahwa kekuatan bersumber pada keharmonisan antara manusia dengan Tuhan dan leluhurnya. Bagi mereka, rumah tidak hanya berwujud fisik, tetapi ada kekuatan lain yang non-fisik yang selalu melindungi dan menjaganya. Cara mereka menjaga keharmonisan tersebut melalui pelaksanaan berbagai ritual adat, misalnya pada saat membuat rumah yang disebut upacara ngadegkeun imah mulai dari awal sampai dengan selesai dengan tujuan untuk meminta keselamatan dan kelancaran (Nuryanto, 2006). 
Dalam arsitektur Kasepuhan Sinar Resmi, rumah diharuskan berbentuk panggung, yaitu rumah yang lantainya berkolong setinggi $\pm 35-50 \mathrm{~cm}$. Panggung dalam konsep pemikiran masyarakat Kampung Naga berkaitan dengan kosmologi tentang tingkatan tiga dunia; (1) Dunia bawah (ambu handap/buana larang) yang disimbolkan oleh pondasi umpak; (2) Dunia tengah (ambu tengah/buana panca tengah) disimbolkan oleh dinding, dan (3) Dunia atas (ambu luhur/buana nyungcung) disimbolkan oleh atap. Letak rumah panggung berada di tengahtengah, diantara dunia atas dan bawah. Masyarakat Kampung Naga percaya, bahwa rumah panggung merupakan pusat yang memiliki kekuatan netral di antara kedua dunia tersebut.
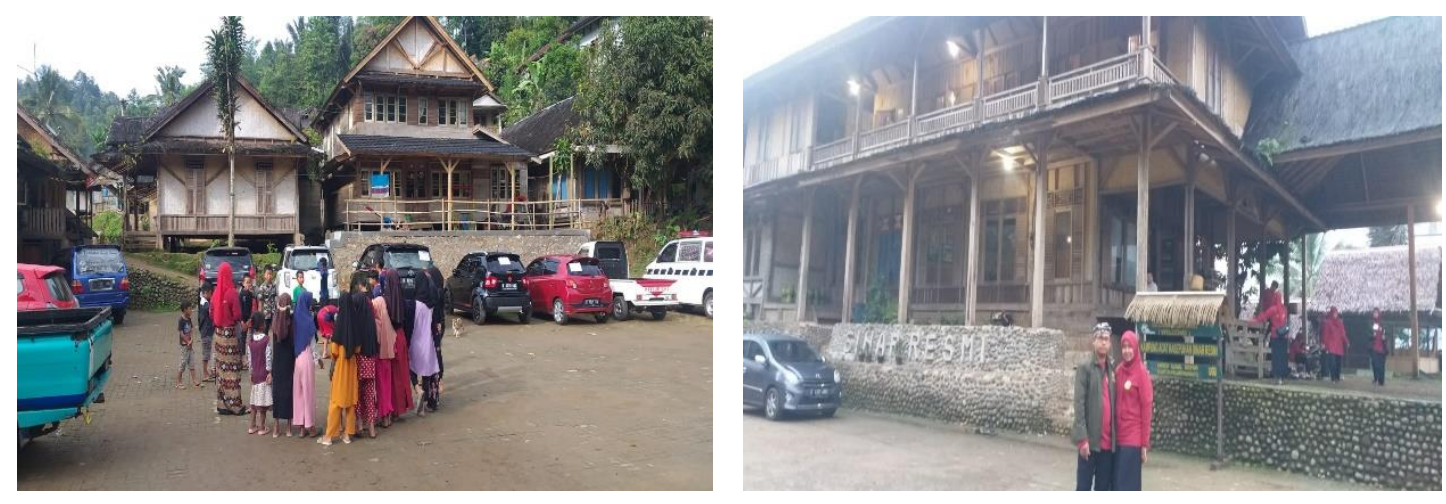

Gambar 1 : Rumah panggung di Kasepuhan Sinar Resmi Sumber: Dokumen Pribadi, 2021

Rumah di Kasepuhan Sinar Resmi dikenal dengan istilah imah atau dalam bahasa halusnya disebut bumi. Rumah dibedakan dalam dua macam bentuk atap yang menjadi ciri rumah-rumah di Kasepuhan Sinar Resmi, yaitu bentuk atap jingjing regis dan julang ngapak. Bentuk atap jingjing regis atau umumnya disebut suhunan jolopong yang memiliki ciri atap curam di kedua sisinya. Jenis atap ini merupakan bentuk atap asli rumah di Kasepuhan Sinar Resmi. Sedangkan atap jenis julang ngapak merupakan pengembangan dari bentuk atap jingjing regis dengan penambahan semacam sorondoy pada salah satu sisinya, sehingga menyerupai sayap burung julang. Atap ini kemudian disebut julang ngapak. Dilihat dari jenis tiang yang dipergunakannya ada dua macam rumah, yaitu rumah dengan tiang yang langsung, sebagai penyangga di bawahnya mempergunakan umpak dari batu lempar (batu ceper) dan imah gagalur yaitu rumah yang penyangganya mempergunakan tatapakan jangkung terbuat dari batu cadas yang dicetak.

Perkembangan arsitektur rumah di Kasepuhan Sinar Resmi dipelopori oleh Abah Ujat dan diteruskan oleh Abah Asep pada tahun 2002. Pembangunan diawali ketika Imah Gede dibangun kembali atau 'ngarehab' di atas lelemah (tanah bekas rumah lama). Perubahan Imah Gede, dewasa ini sudah mempergunakan jendela kaca, lantai yang tadinya dominan talupuh, kini hanya bagian dapurnya saja, sedangkan ruangan lain berlantai papan yang diserut rapih. Menurut Abah Asep, perubahan ini tidak melanggar pamali 
(tabu) yang ditentukan adat, karena tidak mengubah tempat dapur dengan elemennya seperti ruang goah, pangdaringan, parako, talupuh, dan dapur.

Perubahan yang dilakukan oleh Abah Asep Nugraha sebagai sesepuh Kampung Sinar Resmi itu, kemudian diikuti oleh semua penduduk yang misepuh kepadanya. Perubahan yang terjadi dalam pembangunan dan tampilan rumah secara fisik sangat jelas terlihat, rumah-rumah telah memiliki jendela kaca, lantai (tataban) di tengah rumah mempergunakan tataban dari papan sedangkan tataban dari talupuh (lembaran bambu yang dibelah kecilkecil) hanya dipergunakan di dapur saja. Adanya penambahan ruangan kamar tidur, bilik di bagian depan rumah diganti dengan bilahan papan, bahkan ada yang mempergunakan atap genting dan asbes, dan ada beberapa rumah yang memiliki loteng (berlantai dua). Perubahan yang lebih signifikan, yaitu rumah tidak saja mempergunakan material kayu, melainkan sudah mempergunakan adukan semen, seperti layaknya rumah gedung yang ada di luar Kasepuhan Sinar Resmi.

Begitu pula yang terjadi terhadap pelaburan dinding rumah atau bilik, ada yang 'dikapur' atau dilabur dengan kapur berwarna putih seluruhnya atau dikapur hanya bagian-bagian tertentu saja dan ada pula yang mempergunakan cat berwarna pada bagian-bagian tiang atau kusen pintu dan kusen jendela di depan rumah. Abah Asep tidak menyetujui dengan pelaburan dan pemakaian cat berwarna ini, karena menurutnya rumah harus warna alami. Sejatinya rumah adalah gambaran hidup seadanya.

Perubahan lainnya yaitu fungsi kolong. Pada awalnya kolong rumah memiliki ketinggian yang cukup tinggi, karena kolong rumah berfungsi sebagai kandang ternak. Sesuai dengan falsafah yang ada mengenai kolong, yaitu kolong kudu sadungkuk sanagog, supaya katurut ku hayam (tingginya kolong harus setinggi orang berjongkok, agar ayam dapat hidup bersama). Falsafah itu menunjukkan pengertian bahwa ayam adalah hewan yang paling dekat dengan kehidupan manusia. Suara ayam menjadi penentu waktu yang pasti, dengan suara kokokannya yang nyaring pada waktu subuh dapat memberitahukan kepada umat manusia bahwa hari sudah menjelang siang, cepat bangun untuk menjemputrezeki. Begitu pula dalam berbagai acara adat, ayam menjadi hal yang penting, karena ayam dijadikan simbol jiwa dan kehidupan manusia. Seperti apa yang dikatakan Abah: "Sagala ge kudu dihuripan ku hayam" (semuanya harus diberi jiwa oleh ayam). Seiring dengan perubahan yang dilakukan Abah Asep mengenai kesehatan bagi manusia yang harus dijaga dengan benar, maka fungsi kolong dewasa ini hanya dijadikan sebagai tempat penyimpanan alat-alat pertanian, penyimpanan kayu bahan bangunan atau penyimpanan kayu bakar. Hal ini menyebabkan pembuatan tinggi kolong (baik yang disangga dengan mempergunakan batu lempar maupun tatapakan) umumnya seragam berkisar antara 40 sampai dengan 50 $\mathrm{cm}$ dari atas tanah.

Tiang-tiang rumah ditempatkan diatas batu yang lempar atau 'ceper, rata' yang disebut umpak. Sedangkan tatapakan merupakan batu cadas yang dicetak menyerupai bentuk limas dengan ukuran yang sama, yaitu tinggi 40 $\mathrm{cm}$ dan lebar bawah $30 \times 30 \mathrm{~cm}$ dan lebar atas $20 \times 20 \mathrm{~cm}$. Untuk mendapatkan batu tatapakan ini biasanya mereka memesan atau membeli 
dari luar kampung (Kampung Cicadas). Umpak terbuat dari batu bongkahan biasa yang besarnya kira- kira berdiameter $30 \mathrm{~cm}$ dapat dicari dan diambil dari batu-batu yang terhampar di Sungai Cibareno yang tidak jauh dari kampung atau daerah sekitar. Rumah berfungsi sebagai tempat berbagai macam kegiatan kehidupan sehari-hari, menuntut perlakuan yang sangat hati-hati berdasarkan aturan adat istiadat yang berlaku di Kasepuhan Sinar Resmi. Namun dalam perkembangannya aturan-aturan itu tidak lantas menjadi aturan kaku yang tidak dapat berubah sehingga mengikat masyarakatnya dalam menghadapi pengaruh modernisasi dan teknologi baru. Hal ini berlaku pada sistem tekonologi yang dipergunakannya. Pada awalnya teknologi yang dipergunakan dalam pembangunan rumah khususnya dalam membuat rangki atau rangkay (struktur kayu) sangat sederhana. Hubungan antara batang kayu yang satu dengan yang lainnya tidak mempergunakan paku, mereka hanya mempergunakan pen atau paseuk (paku yang terbuat dari bambu atau kayu). Kini untuk memperkuat hubungan kayu, mereka telah mempergunakan paku besi. Menurut cerita seorang tukang bas (ahli bangunan), dahulu untuk memperkuat hubungan kayu ini mempergunakan tali rotan, tali injuk atau tali dari bambu.

Rangka rumah pada umumnya terbuat dari kayu yang didapatkan dari kebun di luar hutan larangan, tempatnya jauh dari perkampungan dan Taman Nasional Hutan Gunung Halimun. Pengertian mengenai hutan atau leuweung, mereka mengenal adanya leuweung tutupan, leuweung titipan, leuweung cawisan, dan leuweung garapan. Leuweung tutupan adalah hutan yang tidak boleh diganggu sedikitpun, sehingga keadaan hutan ini sangat perawan. Leuweung titipan adalah hutan yang masih dapat diganggu apabila dalam keadaan terpaksa, misalnya tidak ada lagi kayu yang dapat diambil dari leuweung cawisan untuk kepentingan adat atau membuat rumah. leuweung cawisan adalah hutan yang sudah diperuntukkan bagi masyarakat, sehingga hutan ini merupakan hak masyarakat sehingga dapat dijadikan permukiman. Leuweung garapan adalah hutan yang dapat dikerjakan demi kebutuhan seluruh masyarakat, baik untuk keperluan sehari-hari maupun keperluan adat.

Rumah yang dahulu hanya berjendela satu dan tidak menggunakan kaca, kini dengan kesadaran yang diberikan oleh Abah Asep mengenai kesehatan dan sirkulasi udara, rumah- rumah telah menggunakan banyak jendela dan berkaca. Perubahan ini pun berpengaruh pada kebutuhan akan perabot rumah tangga, mereka telah pula memiliki barang-barang elektronik seiring dengan masuknya jaringan listrik seperti kulkas, kompor gas, ranjang dan lemari. Bahkan peralatan elektronik seperti TV, handphone, radio, parabola, yang menjadi pola hidup modern. Apabila dihitung jumlah penduduk yang telah memiliki parabola, sebanyak 17 buah. Hal ini menunjukkan bahwa informasi dan hiburan telah menjadi kebutuhan yang harus dipenuhi.

Proses adaptasi dibarengi dengan kearifan manusianya agar kehidupan harmoni terjalin antara manusia dan alamnya. Proses adaptasi manusia dengan alamnyamerupakan keharmonisan dan keselarasan yang harus terus dijaga, sehingga hubungan yang harmonis ini menyebabkan manusia dan alamnya menghasilkan keselarasan dan keseimbangan hidup. Hal tersebut dapat dilihat 
dari segi arsitektural rumah yang sangat adaptif dengan alam sekitarnya. Pembuatan atap dari hateup dan injuk, jenis atap yang berbentuk julang ngapak adalah proses adaptif manusia untuk menyelaraskan diri dengan alam lingkungannya agar manusia terjaga dari rasa dingin. Atap yang terbuat dari genting sangat ditabukan, karena apabila ada rumah yang mempergunakan genting dikatakan paeh samemeh paeh (sudah mati sebelum mati). Maksudnya atap dari genting (terbuat dari tanah) menunjukkan pengisi rumahnya sama dengan orang yang sudah mati dikubur. Untuk kekokohan halaman yang berkontur di lembah, dengan kearifannya diperlukan keahlian membuat benteng yaitu menata batu untuk menyangga tanah agar tidak terjadi longsor.

Sistem pembagian ruangan pada rumah tempat tinggal berhubungan dengan pandangan masyarakat tentang kedudukan dan fungsi masing-masing anggota keluarga penghuni suatu rumah. Pembagian itu didasarkan pada tiga daerah yang terpisah dibedakan penggunaannya, Pembagian fungsi ruangan ini memang tidak begitu kentara, namun ketika ruangan itu dibuka untuk difungsikan, maka ada pembagian khusus. Dalam penggunaannya orang tidak dapat sembarangan untuk memasukinya. Demikian pula ketika seorang lakilaki dilarang memasuki daerah pangdaringan/goah 'lumbung tempat menyimpan beras' akan sangat berkaitan dengan kepercayaan yang sakral.

Dalam Imah Gede, memiliki simbol- simbol Tritangtu yang dapat dilihat dalam beberapa aspek seperti yang diuraikan di bawah ini: (1) Tihang (tiang) mempunyai makna ajegna kahirupan (tegar dan tegaknya kehidupan). (2) Bilik yang dipasang di empat penjuru, menunjukkan opat kalima pancer, diwatek tina opat dina kahirupan (bilik yang dipasang di tengah rumah di keempat sisi rumah). (3) Sungsuhunan nu segi tilu sama sisi, urang teh kudu ngajaga ucap, ngajaga tekad, jeung laku lampah, kudu bisa ngaulaan nagara, mokaha oge nyanghulu ka hukum, nunjang ka nagara, mupakat jeung balarea. (Atap yang menyerupai segitiga sama sisi artinya harus menjaga ucapan, tekad, dan perilaku, harus hormat kepada negara, hukum, dan bermufakat). (4) Teras nu buleudna, ngabogaan makna kabuleudan tekad urang di mana-mana hirup atawa uih teh pasti ka mana. (Bentuk $\mathrm{O}$ di atas atap memiliki makna kebulatan tekad, walaupun kita berada di mana saja, pasti akan kembali ke haribaan- Nya). (5) Tihang (tiang) yang ditopang oleh bilik yang ada di keempat sudut wetan, kidul, kulon, kaler (timur, selatan, barat dan utara) menandakan makna kehidupan yang kuat. (6) Siku-siku sebagai peneguh dan penguat tiang kehidupan atau keajegan hidup. Menurut Abah, dengan keajegan ini kita akan "Apal kanu hirup, apal kanu ngahirupanana. Apal kanu cicing, apal kanu nyicingkeunana, aya dina raga badag urang. Nu aya di badan awaking. Cageur bageur, hirup tetep tumaninah, tiis ceuli herang mata, subur makmur loh jinawi, rea ketan, rea keton, murah sandang murah pangan, hirup aing salamet dunya aherat. Tos ngadeg kitu urang deukeut jeung nu kagungannana Dina jawa mah manunggaling gusti, dina Sunda mah Nganti ka gusti ngaraga jeung nu kawasa.eta harti buleud tea". (Mengerti hidup, kenal kepada yang menghidupi, mengerti diam dan kenal kepada yang mendiamkan, semua ada dalam diri kita. Sehat dan bageur, hidup tenang tidak ada gosip, subur murah sandang murah pangan, hidup harus selamat di dunia dan akhirat). 
Rumah milik masyarakat Kasepuhan Sinar Resmi memiliki tata ruang sebagai berikut; tengah imah, kamar (kamar tidur), dapur, dan goah. Ruang tengah imah dan kamar merupakan satu kesatuan, karena berada di ruang depan sebuah rumah. Sedangkan goah dapat dikatakan sebagai ruang utama dalam sebuah rumah, karena goah sama artinya dengan pabeasaan yaitu tempat menyimpan beras sebagai bahan makanan. Penempatan ruang - ruang tersebut antara dapur, parako atau tungku dan goah merupakan satu kesatuan yang tidak dapat dipisahkan sehingga ditempatkan di depan, dibanding dengan kamar tidur yang berada di belakang goah atau dapur. Rumah memiliki arti yang sangat spesifik. Dalam bahasa Sunda lemes 'halus' rumah berarti bumi artinya dapat beranalogi sebagai jagat alam semesta yang menampung berbagai aspek kehidupan di dalamnya. Pengertian rumah atau bumi menuntut kesadaran yang penuh tanggung jawab dari orang sebagai penghuninya. Hal tersebut dapat dilihat dari aturan yang digariskan oleh karuhunnya dalam tata cara mendirikan rumah, begitu pula penempatan ruang- ruang yang ada di dalamnya harus sesuai dengan tatali karuhun yang seharusnya. Pembangunan dimulai pada hari yang telah ditentukan dan dipandang sebagai hari baik bagi si pemilik rumah, dalam membangun rumah bagi si anak atau si adik, tidak boleh berada di sebelah timur, karena akan ngalangkangan 'membayangi' rumah orang tua atau kakaknya, bila hal itu dilanggar maka akan mengakibatkan bencana. Dalam praktiknya belum pernah ada pembangunan rumah seperti itu. Dalam pengorganisasian ruang-ruang dalam rumah pun harus ditaati selaras tata aturan tatali karuhunnya, walaupun perubahan demi perubahan terus terjadi dan berlanjut dari hari ke hari. "Boleh terjadi perubahan namun hal-hal pokok tidak boleh dirempak atau 'dilanggar'.

\section{KESIMPULAN}

Kearifan lokal (local wisdom) Arsitektur Tradisional Kasepuhan Sinar Resmi yang sangat kaya nilai dan makna tentang sistem struktur dan konstruksi rumah panggung yang dapat dikembangkan sebagai bangunan ramah gempa dalam mitigasi bencana yang didasarkan pada beberapa kriteria, yaitu: (1) Bentuk panggung yang simpel dengan pondasi umpak/tatapakan mampu mengimbangi gerakan horisontal-vertikal gempa bumi, karena letaknya di atas permukaan tanah; (2) Bentuk panggung juga menjadi inspirasi bagi model rumah yang ramah terhadap gempa bumi, karena strukturnya yang cenderung ringan dengan dominasi bahan yang ringan, seperti papan, bilik bambu, lantai talupuh, dll.; (3) Bentuk kolong pada struktur rumah panggung berfungsi sebagai penjaga keseimbangan antara bangunan dengan gerakan lempeng tanah, sehingga tetap ramah (mampu mengimbangi) terhadap gaya yang ditimbulkan oleh gempa.

Dalam kajian arsitektur tradisional, kita perlu memahami secara mendalam tentang masyarakat dan budayanya, karena hal tersebut merupakan subjek yang sangat penting. Hal itu disebabkan bahwa Arsitektur selalu berkaitan dengan konteks budaya di mana arsitektur itu berada. Perubahan budaya sekecil apapun yang menimpa masyarakatnya, maka arsitektur pun akan ikut berubah. Sejarah membuktikan bahwa budaya dan arsitektur selalu membuka 
diri pada proses perkembangan yang datangnya dari luar. Budaya dan arsitektur pada dasarnya tidak pernah statis, melainkan dinamis sepanjang masa yang selalu menyesuaikan diri dengan situasi dan kondisi masyarakatnya. Rumah bagi masyarakat Kasepuhan Sinar Resmi dalam kesehariannya dapat berfungsi sebagai tempat menyimpan bahan makanan yaitu dengan adanya goah dan pangdaringan di dalam rumah. Selain itu imah berfungsi sebagai tempat istirahat, tidur dan meneruskan keturunan dengan adanya ruang pangkeng atau geusan. Dalam lingkup yang lebih jauh, imah dapat berfungsi sebagai tempat upacara atau selamatan daur hidup mulai dari kehamilan, kelahiran, perkawinan sampai kematian. Pembangunan sebuah rumah tak lepas dari ritus yang secara adat selalu dipatuhi dan dilaksanakan dengan benar, hal tersebut sangat erat kaitannya dengan sistem kepercayaan yang mereka anut. Kenapa hal itu dilaksanakan, karena mereka takut akan melanggar pamali. Demikian pula rumah dan pola perkampungan yang ada di Kasepuhan Sinar Resmi erat hubungannya dengan alam sekitar, sehingga rumah dapat dianalogikan sebagai 'mikro kosmos' atau bumi 'makrom kosmos' yang berarti alam semesta.

\section{REFERENSI}

Adimihardja, K. (1995). Sejarah Perkembangan Masyarakat di sekitar Gunung Salak, Gunung Gede Pangrango dan Gunung Halimun. Tarsito.

Adimihardja, Kusnaka et al. 1981. Tipe Rumah Tradisional Khas Sunda Jawa Barat. Kanwil Direktorat Jenderal Pariwisata Jawa Barat.

Harum, I. B. (2011). Arsitektur Rumah dan Pemukiman Tradisional di Jawa Barat. Dinas Pariwisata Dan Kebudayaan Provinsi Jawa Barat.

Garna, Yudistira. (1984). Pola Kampung dan Desa, Bentuk serta Organisasi Rumah Masyarakat Sunda. Pusat Ilmiah dan Pengembangan Regional (PIPR) Jawa Barat, Bandung.

Koentjaraningrat. (2015) Kebudayaan, Mentalitet dan Pembangunan. Penerbit PT Gramedia.

Mulyana, Deddy. (2001) Metodologi Penelitian Kualitatif. Paradigma Baru Ilmu Komunikasi dan Ilmu Sosial Lainnya. Remaja Rosdakarya.

Humaeni, A., \& Humaeni, A. (2018). Budaya Masyarakat Kasepuhan Ciptagelar Sukabumi Jawa Barat.

Oliver, Paul. 1987 Dwelling-The Houses Across the World. Phaidon Press Limited.Oxford Pudjiastuti, S. R. (2019). Mengantisipasi Dampak Bencana Alam. Jurnal Ilmu Pendidikan (JIP) STKIP Kusuma Negara Jakarta, 10(2), 1-14.

Pudjiastuti, Sri Rahayu. (2019) Penelitian Pendidikan, Yogyakarta: Media

Akademi.

Rusnandar, Nandang (2000), Arsitektur Adat Tradisional Kampung Mahmud, Bandung:BPNST.

Sumintardja, D. (1966). Kompendium sejarah arsitektur. Lembaga Penjelidikan Masalah Bangunan.

Harapan, A. (2008). Kearifan lokal rumah vernakular di Jawa Barat bagian selatan dalam merespon gempa. EMAS Jurnal Sains dan Teknologi, 18(2), 123-134. 